\section{The Impact of Human Capital Management and Resiliency on Employees Productivity}

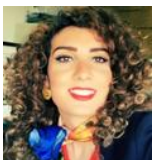

International Journal of Economics, Business and Management Studies Vol. 7, No. 1, 153-166, 2020 e-ISSN: 2226-4809/p-ISSN: 2304-6945

Human resources practices are considered one of the most important practices which should be practiced to maintain effective and efficient operations in the workplace. To increase the performance of alpha banks in Lebanon, Human Resources Development practices is the most important method that associations effort to retain the capability stages of their human resources. Since the Lebanese Banks in general and the Alpha banks in specific are facing a high employee turnover rate in the workplace because of absence of employee engagement practices and absence of talent management programs and human capital programs- the thing which demotivated employees and pushed them to search for a new job that best suits their needs and ambitions to develop their career. The Lebanese Banking Sector has been suffering recently from a fluctuation in its performance due to absence of efficient and effective human resources- practices in the workplace which resulted in a high turnover rate and by that affecting the overall productivity. The research will implement a mixed approach throughout distributing surveys over 370 participants in the Lebanese Alpha Banks, and through conducting in-depth interviews with managers in the Lebanese Alpha Banks. The research findings complied with the literature review findings and proved that the higher the empowerment, the higher the employees' performance will be reflecting a higher productivity.

Keywords: Mimetic isomorphism, Empowerment, Human capital development, Resilience, Performance.

JEL Classification: 251.

DOI: $10.20448 / 802.71 .153 .166$

Citation | Nancy Askar (2020). The Impact of Human Capital Management and Resiliency on Employees Productivity. International

Journal of Economics, Business and Management Studies, 7(1): 153-166.

Copyright: This work is licensed under a Creative Commons Attribution 3.0 License

Funding: This study received no specific financial support.

Competing Interests: The author declares that there are no conflicts of interests regarding the publication of this paper.

History: Received: 27 May 2020/ Revised: 29 June 2020/ Accepted: 7 August 2020/ Published: 31 August 2020

Publisher: Online Science Publishing 


\section{Highlights of this paper}

- The research will implement a mixed approach throughout distributing surveys over 370 participants in the Lebanese Alpha Banks, and through conducting in-depth interviews with managers in the Lebanese Alpha Banks.

- The research findings complied with the literature review findings and proved that the higher the empowerment, the higher the employees' performance will be reflecting a higher productivity.

\section{INTRODUCTION}

Human resources practices are considered one of the most important practices which should be practiced to maintain effective and efficient operations in the workplace.

To increase the performance of alpha banks in Lebanon, Human Resources Development practices is the most important method that associations effort to retain the capability stages of their human resources. Since the Lebanese Banks in general and the Alpha banks in specific are facing a high employee turnover rate in the workplace because of absence of employee engagement practices and absence of talent management programs and human capital programs- the thing which demotivated employees and pushed them to search for a new job that best suits their needs and ambitions to develop their career. The research will consider the effect of Human Resource Development on employees' performance taking employee resilience, engagement and mimetic isomorphism as moderators.

The general objective of the research is to consider the impact of human capital development on employees' performance.

In this study the specific objectives included were:

- Studying the impact of empowerment on employee performance.

- Studying the impact of mimetic isomorphism on employee performance.

- Studying the impact of resilience on employee performance.

\section{THEORY AND HYPOTHESES DEVELOPMENT}

\subsection{Human Capital Management and Employee Performance}

The importance of human capital management and Talent management has a direct relationship with employee motivation, and by that, it has a direct impact on the performance of the employees at work. It aims at contributing employees and involving them in the decision making process in human capital management (Ajisafe, Orifa, \& Balogun, 2015).

Risks are major factors for human capital management, therefore banks must keep enough capital supervision to cover human capital management and potential losses from risks. According to the committee of human capital management and credit institutions and banks, they have the opportunity to use human capital management internal rating based system when determining the minimum capital requirements (Ajisafe et al., 2015).

Obisi and Anyim (2012) had different tools to motivating employees, compensating them, enhancing communication, at last evaluating human capital management and the performance of the employees, and enhancing their career growth in human capital management. This can be done through the means of finding a suitable way to implement human capital management and performance appraisals system in the firm to motivate them and enhance their productivity. In addition, Dawodu (1998) studied the influence of human capital management and training and development on the bank in Nigerian banking in the First Bank of Nigeria. 
Referring to the above human capital management statistical graphs, to the interviews in human capital management conducted with employees and managers, to the chi-square analysis, and to the Chi-square statistical method, Dawodu (2011) conducted many solutions in human capital management.

Basel Two has established a direct link between minimum regulatory capital and human capital management underlying human capital management, market risk and corporate risk exposure of banks. This step gives an indication that capital management is an important stage in risk management and evaluation (Hill \& Lent, 2006); (Satterfield \& Hughes, 2007) but unfortunately, this model failed to achieve its objectives in human capital management in an effective and efficient manner with employees who aim at achieving human capital management in a good career path and want to learn and develop their skills (Kraiger, 2002).

Barber (2004) is recognized as being one of the dynamic important writer in many institutions in the world defending human capital management, through a proper training that can improve the quality and knowledge of employee which definitely help to improve the human market.

During this important and precise period, it should have closely worked as a decision maker with the current operations unit in general and most especially with the performance human theory unit and human capital management. Moreover, all financial transactions are monitored by this unit on daily basis that they are in compliance with the instructions and recommendations of the General federation. We are living in an era which dominate the technological modernization in a large number of capacity developments, Activities and human capital management Research Projects that brought many innovations in different sectors in a positive performance.

Hypothesis One: There is positive relationship between human capital management and employees performance.

\subsection{Mimetic Isomorphism and Employee Performance}

Mimetic isomorphism can be defined as an organizational theory in which an organization tends to manage another structure of another organization in order to enhance productivity, and this usually takes place when organizational goals are not clear, or the procedures required to achieve the goal are not determined.

Previous studies were done by Abigail (2009) to study the importance of mimetic isomorphism over a sample of 200 employees in Nigerian Banks throughout relying on the quantitative methodology to collect data. The SPSS statistical tool had been used to analyze the data and the results proved that there is a direct positive relationship between mimetic isomorphism and employee performance. This can allow the employees to cope with change and enhance productivity on the long run.

However, on the other hand another research done by Mitchel (2007) proposed over a sample of 300 employees in German Banks, throughout implementing a mixed approach to collect data. He was able to achieve a response rate of $80 \%$, which is considered a high rate, and the data was analyzed using the SPSS statistical tool.

The results showed that there is a direct relationship between mimetic isomorphism and employee performance and that depends on how the human resources deal with it. It was recommended in his study that human resources should provide the employees with the required tools and programs to cope with change and achieve higher development and by that achieving better performance and productivity.

Hypothesis Two: There is positive relationship between mimetic Isomorphism and employees' performance.

\subsection{Resilience and Employee Performance}

Employee engagement is positively associated with expected institutional support as a concept (Kurtessis, 2015; Mathumbu \& Dodd, 2013). Research by Rothmann and Rothmann (2010) indicates that a strong indicator of employee engagement in various South African sectors is institutional assistance. This association is backed up in 
the context of sales by the competitive complexity of sales jobs followed by exhaustion, which ultimately has significant implications for the level of commitment and need for institutional support (Kurtessis, 2015).

There is a correlation between resilience and engagement in different studies (Bakker \& Leiter, 2011). Resilience seems to be closely associated with performance, one of the three measurements of employee engagement (González, 2003). Medhurst (2011) similarly deduced that because when confronted with difficult situations, resilience positively affects sales growth.

Bande (2015) suggests that resilience can lead in a qualitative well-being assessment requiring engagement Simons (2013) find a realistic and highly significant relationship among total job results and resilience among customer support employees in the South African background. In terms of the negative impact of emotional exhaustion on a well-being of workers, the call center setting is equivalent to a dynamic sales role (Johnson, 2005). South Africa seems not to have published studies investigating the relationship between employee engagement and resilience in a sales environment.

Hypothesis Three: There is a positive relationship between resilience and employees performance

\subsection{Empowerment and Employee Performance}

Another essential component in the existing literature, as described by the theoretical framework, is employee empowerment that is one of the independent variables.

The essential component of this study is employee empowerment which is one of the independent variables, is few other sAs found by conceptual framework.

The meaningful connection between such two major phenomena, such as employee empowerment and employee performance, was shown by few other studies based on observable observations.

Yadav (2015) have revealed some aspects of employee empowerment in Indian micro-lending facilities. Singh (2011) conducted the same kinds of studies in the service sector, discussing the topic in Latin America and India's program management, transportation and technology businesses.

While the main determining components identified as dependent factors based on independent variables such as worker empowerment etc. are reported to be separately defined, the impact of the same performance of workers has always been found to be optimistic from the above research.

Hypothesis Four: There is a positive relationship between Empowerment and Employee Performance.

\section{METHODOLOGY}

This section will include the sample size, sampling frame, target population, sampling methods, data type or collection method, or source of data that will be implemented in the research

\subsection{Target Population}

The Lebanese Banking Sector consists of the target population which includes both employees and manager. The main cause of research was to examine the effect of Human Capital Development on employees achievement or inspiration.

\subsection{Sampling Technique}

According to Patton (1990) for the determined the sample frame the researcher used purposive sampling technique. Purposive sampling referred to like- decision discriminating and biased example is a non-possibility 
sampling technique that is distinguished by a purposeful attempt to increase delegate samples by with collections and usual regions in a sample, the investigator relies on his/her choice to decide sample group associates.

\subsection{Sampling Frame}

The top ten alpha banks in Lebanon will be addressed to study the impact of human capital management practices on the employees' performance. The researcher was able to target 370 responses which is considered a good sample to conduct the research analysis.

\subsection{Sample Size}

The sample size had resolute as of sample frame of 370 bank employees or executives from the top ten alpha banks in Lebanon. From Human Resources Development department in Lebanese Alpha Banks data was collected with interviewing eight managers. To study the effect of Human Resource Development climate on employees' achievement or motivation overall of 24 questionnaires were discrete to collect appropriate data to study the impact of human capital on employees performance taking into consideration employee resilience, empowerment and mimetic isomorphism.

\subsection{Sources of Data}

The main source of data for focused is used by the researchers. By the junior specialists, senior specialists or executives of the Alpha Banks head office the primary data was composed.

\subsection{Data Type and Data Collection}

The primary data was composed throughout as of actual occurrence in data collecting. In this study there was the primary source of data employed from prepared questionnaire or planned interview.

A planned questionnaire including 24questions that were considered or managed by utilizing a 5 point Likert response level developed that comprises (a) strongly disagree, (b) disagree, neutral (c), agree (d) or strongly agree (e) to support contribution. Functioning in the case of Alpha Banks by the investigator, the questionnaire dispersed to indiscriminately choose junior specialists, senior specialists or executives. The main reason of the questionnaire was to inspect the effect of Human Resource Development climate on employees' achievement or motivation. For HRD department Director The semi-structured interview was conducted or in the different head offices, Human Resource Development Case Team manager from HR department. Both the surveys and interviews will be distributed using google forms for data collection and then will be analyzed using the SPSS statistical tool, and AMOS for Structural Equation Modeling.

\subsection{Data Processing}

The investigator completed data cleaning in which the composed raw data was condensed to notice mistakes or oversights or cross ensured whether the questions are answered correctly or consistently or transmission numerical was followed in data processing. By the researcher in order to make certain logical wholeness or reliability of responses, data editing or coding were carried throughout using the SPSS statistical Package.

\subsection{Data Analysis}

Depending on the sources of information the researcher has composed the data, prepared or planned the dissimilar data. Both qualitatively and quantitatively data were analyzed. The quantitative data examination was 
completed through using SPSS and AMOS software. The methods for quantitative data examination were the occurrence sharing or proportions next to association which utilized to decide the amount of respondents selecting the different answers or to see the correlation among Human Resource Development or achievement or motivation. This was completed for every collection of items connecting to the study query or purposes. Evocative statistical outcomes that were obtainable in tables or charts were too utilized to make certain simply considerate of the investigation.

\subsection{Reliability Test}

For a sample of examinees it is usually utilized as a determined of the inside constancy and dependability of a psychometric test score. Coefficient of reliability is proportional Cronbach's alpha. Therefore, Coefficients of .90 or superior are almost forever appropriate, .80 or superior is suitable in mainly circumstances, or .70 may be suitable in a few examining studies for several indices according to Lombard (2010).

\subsection{Research Model}

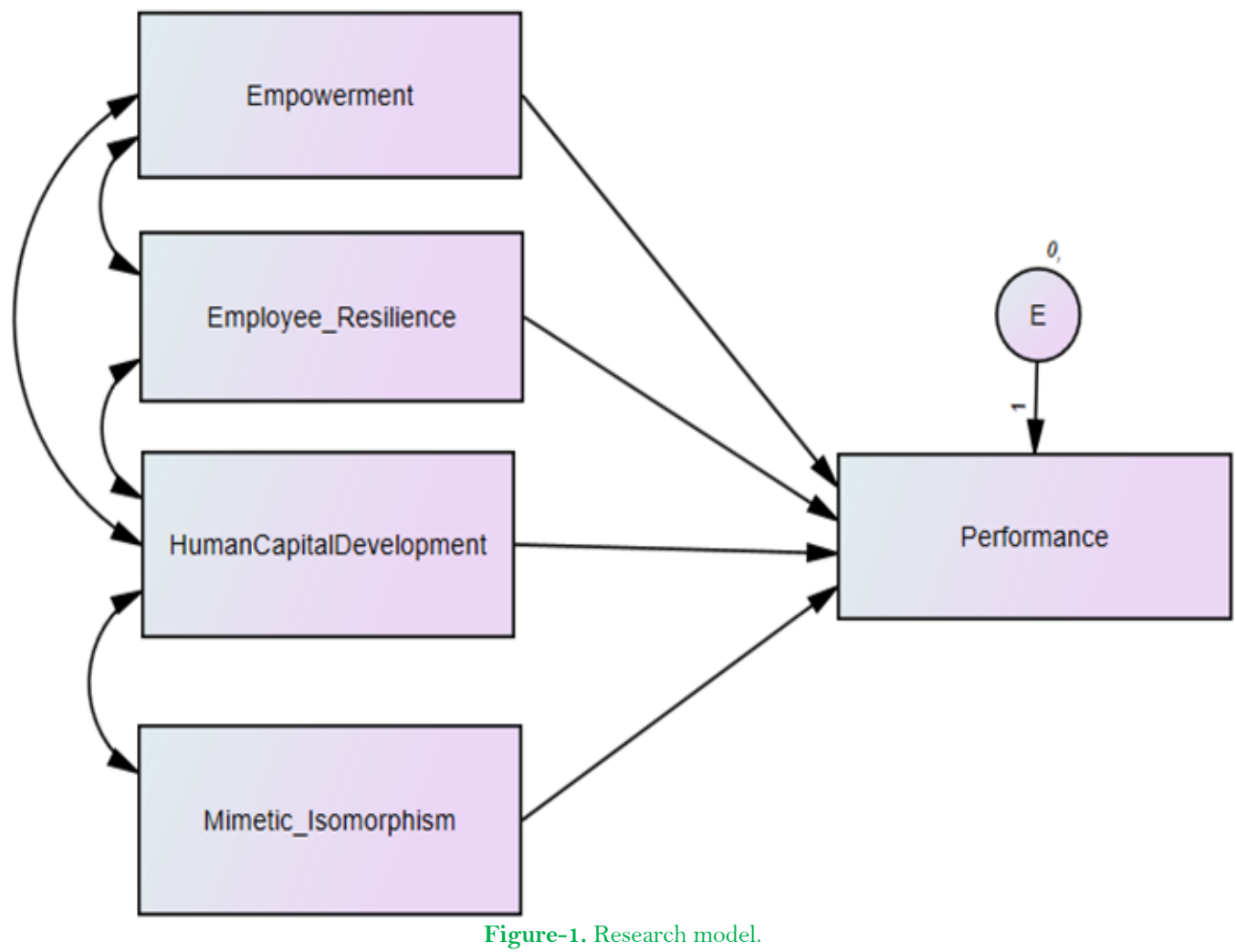

The above figure elaborates the research model that will be implemented in the research. The above model includes the independent and dependent variables as well as the moderator variables which will be used to construct the research hypotheses.

The dependent variable is: Performance.

The independent variable is: Human Capital Management.

The mediator variables are: Employee empowerment and Employee Resilience.

The moderator variable is: Mimetic Isomorphism.

Based on the above model, the research hypotheses can be constructed as follows: 
H1: There is correlation between human capital development and performance taking employee resilience as a mediator.

H2: There is correlation between human capital development and performance taking employee empowerment as a mediator.

H3: There is correlation between human capital management and performance taking mimetic isomorphism as a moderator.

The following hypotheses will be validated in the coming sections of the paper

3.12. Factor Analysis

Table-1. Reliability analysis.

\begin{tabular}{lc}
\hline & $\mathbf{1}$ \\
\cline { 2 - 2 } Human Capital Development & .742 \\
Employee Resilience & .718 \\
Mimetic Isomorphism & .768 \\
Performance & .790 \\
Empowerment & .779 \\
\hline
\end{tabular}

The reliability analysis is an analysis which aims at testing whether the collected data is valid and reliable for statistical analysis or not based on an indicator called Cronbach Alpha. Each variable consists of statements. The reliability analysis aims at conducting an average for the results of these statements in order to be able to detect if there is any bias and from which variable it comes.

The Cronbach Alpha results for the variables are as follows:

- Human Capital Development indicates a Cronbach Alpha of 0.742

- Employee Resilience indicates a Cronbach Alpha of 0.718

- Mimetic Isomorphism indicates a Cronbach Alpha of 0.768

- Employee Performance indicates a Cronbach Alpha of 0.790

- Empowerment indicates a Cronbach Alpha of 0.779

All of the variables indicated an acceptable level of Cronbach Alpha since all variables scored a ratio of 0.7 and above indicating an acceptable level; and by that the data collected are statistically significant and ready for statistical analysis.

\section{ANALYSIS}

This section will address three regression models in order to study the effect of the mediating and moderating variables over the dependent and independent variables. However, three regression models will be implemented which as follows:

- The first regression will study the relationship between human capital development and performance

- The second regression will study the relationship between human capital development and performance but adding on them employee resilience and empowerment as mediators.

- The third regression will study the relationship between human capital development (independent variable) and performance (dependent variable) adding on them the mediating variables (resilience and empowerment) and the moderator (mimetic isomorphism). 
Table-2. Regression.

\begin{tabular}{ccccc}
\hline \multicolumn{4}{c}{ Model Summary } \\
\hline Model & $\mathbf{R}$ & R Square & Adjusted R Square & Std. Error of the Estimate \\
1 & $.449^{\mathrm{a}}$ & .202 & .200 & .745 \\
\hline a. Predictors: & (Constant), HumanCapitalDevelopment & \\
\hline
\end{tabular}

\begin{tabular}{|c|c|c|c|c|c|}
\hline \multicolumn{6}{|c|}{ Coefficients } \\
\hline Model & \multicolumn{2}{|c|}{$\begin{array}{l}\text { Unstandardized } \\
\text { Coefficients }\end{array}$} & $\begin{array}{c}\text { Standardized } \\
\text { Coefficients }\end{array}$ & $\mathbf{T}$ & Sig. \\
\hline & B & Std. Error & Beta & & \\
\hline (Constant) & 1.150 & .101 & & 11.433 & .000 \\
\hline HumanCapitalDevelopment & .563 & .058 & .449 & 9.649 & .000 \\
\hline
\end{tabular}

The above regression analysis proved that there is a direct relationship between human capital development, and performance since the significance level is below than 0.05; and by that the following hypotheses can be validated:

- $\quad$ There is direct relationship between human capital development and performance.

In this regression, the relationship between human capital and performance is weak since the R-Square is $20.2 \%$ The following model will study the relationship between the dependent and independent variables but adding on them the mediators to study whether the relationship will be stronger or not.

4.2. Regression Model Measuring Human Capital Development and Performance Using Empowerment and Resilience as Moderators

Table-3. Regression.

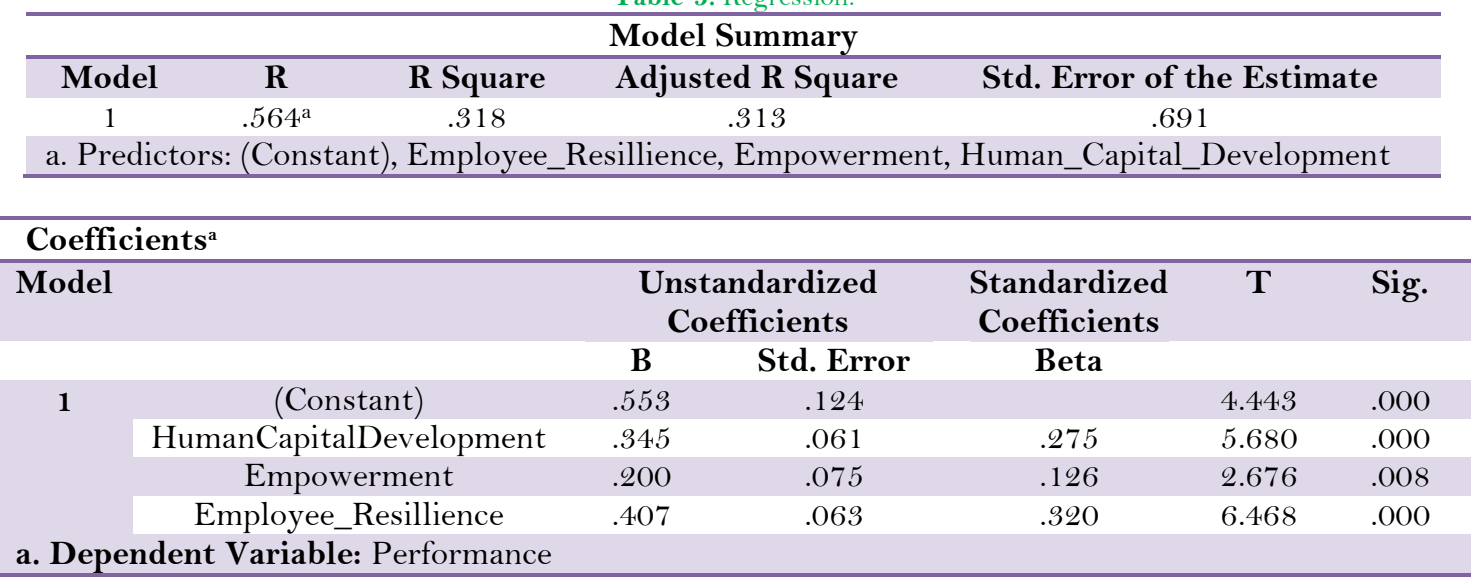

The above regression analysis proved that there is a direct relationship between human capital development, and performance taking employee resilience and empowerment as mediators, and thus based on the above results, the hypotheses can be validated as follows:

There is direct relationship between human capital development and performance taking empowerment and employee resilience as mediators 
In this regression, the relationship between human capital and performance tend to be stronger since the $\mathrm{R}$ square after the inclusion of the mediators in the regression model increased to become $31.8 \%$. As a conclusion the mediators tend to increase the strength between the dependent and independent variables.

The following model will study the relationship between the dependent and independent variables but adding on them the mediators to study whether the relationship will be stronger or not.

4.3. Regression Model Measuring Human Capital Development and Performance using Empowerment and Resilience as Moderators and Mimetic Isomorphism as Moderator

Table-4. Regression Analysis

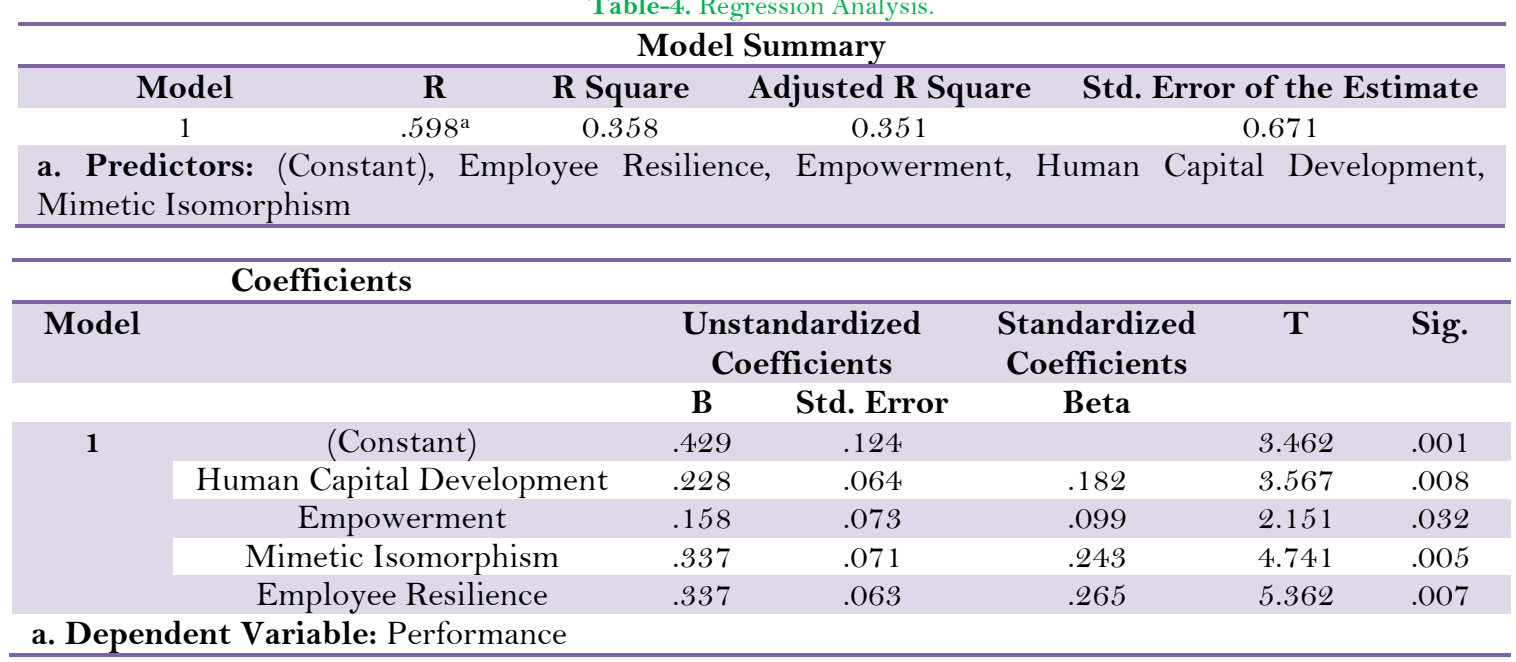

The above regression analysis proved that there is a direct relationship between human capital development, and performance taking employee resilience and empowerment as mediators, and thus based on the above results, the hypotheses can be validated as follows:

There is direct relationship between human capital development and performance taking empowerment and employee resilience as mediators and taking mimetic isomorphism as moderator

In the above regression, the relationship between human capital and performance tends to be stronger since the $\mathrm{R}$ square after the inclusion of the mediators (empowerment and resilience) and the moderator (mimetic isomorphism) in the regression model increased to become $35.8 \%$.

4.4. Pearson Correlations

Table-5. Pearson correlations.

\begin{tabular}{llc}
\hline & & Performance \\
\hline Human Capital Development & Pearson Correlation & $.449^{* *}$ \\
& Sig. (2-tailed) & .000 \\
& $\mathrm{~N}$ & 370 \\
Empowerment & Pearson Correlation & $.323^{* *}$ \\
& Sig. (2-tailed) & .000 \\
& $\mathrm{~N}$ & 370 \\
Employee Resilience & Pearson Correlation & $.482^{* *}$ \\
& Sig. (2-tailed) & .000 \\
Mimetic Isomorphism & $\mathrm{N}$ & 370 \\
& Pearson Correlation & $.480^{* *}$ \\
& Sig. (2-tailed) & .000 \\
& $\mathrm{~N}$ & 370 \\
\hline
\end{tabular}


Pearson correlations test is a test which aims at studying whether the relationship between variables is positive or negative based on an indicator called Pearson Coefficient, and by that the results will be validated as follows:

The statistical results showed a positive relationship between human capital development and performance (0.449) in which the higher the human capital development is, the higher the employees' performance will be and by that reflecting higher productivity.

Furthermore, positive relationship between empowerment and performance (0.323) tends to take place between the mentioned two variables, the higher the empowerment is in the workplace, the higher the employees performance will be. This is based on the fact that employees feel more responsible for the tasks that they are dealing with and by that they are willing to exert extra effort to enhance productivity.

Furthermore, the research findings showed a positive relationship between employee resilience and performance (0.482), in which this relationship is known as a proportional relationship; the higher the employee resilience is, the higher the employees performance will be in the workplace.

At last, the findings showed a positive relationship mimetic isomorphism and performance (0.480); the higher the mimetic isomorphism rate is, the higher the employees performance will be in the workplace.

However, a comparison between the research findings and the literature review findings will be provided in the following Table 6:

Table-6. Comparison between research findings and literature findings.

\begin{tabular}{ll}
\hline Research Findings & Literature Findings \\
\hline $\begin{array}{l}\text { Positive Relationship between Human Capital } \\
\text { Development and employees performance }\end{array}$ & $\begin{array}{l}\text { Obisi and Anyim (2012) proved that there is a positive } \\
\text { relationship between human capital development and } \\
\text { employees performance }\end{array}$ \\
$\begin{array}{l}\text { Positive relationship between empowerment } \\
\text { and employees performance }\end{array}$ & $\begin{array}{l}\text { Yadav (2015) proved that the higher the empowerment } \\
\text { practices are implemented in the workplace, the higher the } \\
\text { employees productivity will be } \\
\text { Positive relationship between resilience and } \\
\text { employees performance }\end{array}$ \\
$\begin{array}{l}\text { Positive relationship between mimetic } \\
\text { employees performance in the workplace. }\end{array}$ \\
isomorphism and employees performance
\end{tabular}

\subsection{Relationship among the Variables}

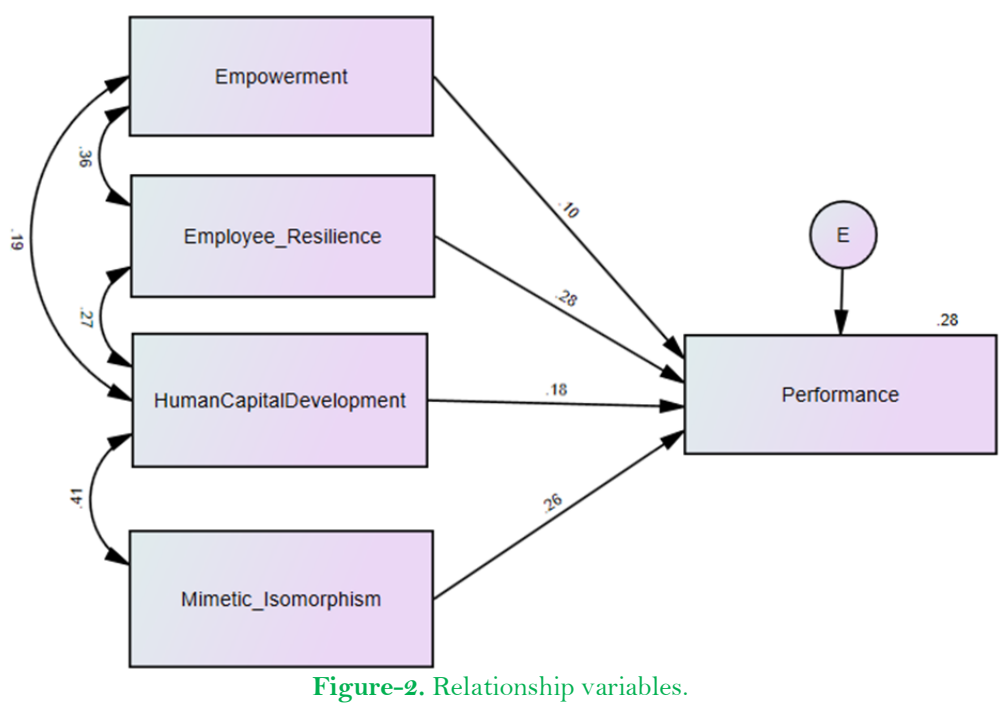


The following model had been implemented using AMOS in order to test the relationship between the endogenous and exogenous variables and the mediator variables, and by that the results will be as follows:

- The relationship between empowerment and performance indicated a ratio of 0.10

- The relationship between employee resilience and performance indicated a ratio of 0.28

- The relationship between human capital development and performance indicated a ratio of 0.18

However, the effect of the mediating variables on the independent variable will be explained as follows:

- Employee resilience tends to affect human capital development by 0.27

- Employee resilience tends to affect empowerment by 0.36

- Empowerment tends to affect human capital development by 0.19

- Empowerment tends to affect employee resilience by 0.36

As for the moderating variable, it has the following effect on the dependent and independent variables:

- Mimetic Isomorphism tends to affect human capital by 0.51

- $\quad$ The relationship between mimetic isomorphism and performance indicated a ratio of 0.26.

\section{MAIN FINDINGS}

After collecting the data using the google forms and after conducting the regression analysis using the SPSS statistical tool, the results will be viewed as follows taking into consideration that the confidence interval level used to test the hypotheses is $95 \%$, and by that the hypotheses can be tested as follows:

There is direct relationship between human capital development and performance.

There is direct relationship between human capital development and performance taking empowerment and employee resilience as mediators

There is direct relationship between human capital development and performance taking empowerment and employee resilience as mediators and taking mimetic isomorphism as moderator

The following equation can be conducted to validate the regression analysis:

$\mathrm{Y}=\mathrm{A}+\mathrm{BX}_{1}+\mathrm{BX}_{2}+\mathrm{BX}_{3}+\mathrm{BX}_{4}$

$\mathrm{Y}=$ dependent variable, $\mathrm{A}=$ constant, $\mathrm{B}=$ Coefficient and $\mathrm{X}=$ independent variables + Moderators

Employee Performance $=\mathrm{A}+0.008 \mathrm{HCD}+0.032$ Empowerment +0.005 Mimetic Isomorphism +0.007 Employee

Resilience

The following can be concluded from the equation:

For every one unit increase in HCD, employee performance is affected by 0.008

For every one unit increase in Empowerment, employee performance is affected by 0.032

For every one unit increase in mimetic isomorphism employee performance is affected by 0.005

For every one unit increase in resilience, employee performance is affected by 0.007

All the results tend to be significant and proportionally related to each other.

The findings also showed that the R-Square between the dependent and independent variable is $20.2 \%$, but after adding the mediating variables (resilience and empowerment) the R-Square increased to $31.8 \%$, and after adding the moderator variable (mimetic isomorphism) the strength of the model increased to reach $35.8 \%$.

It can be concluded that the mediators and the moderator tend to increase the strength between the human capital development and performance. 


\section{CONCLUSIONS}

The main reason of this research was the effect of Human Resource Development climate on employees' abilities to access of performance and motivation in Lebanese Alpha Banks. The studies have the following conclusions due to the analysis and findings.

For improving its employee's knowledge and skills the banks are practicing the Human Resource Development manual or dedicated and further education in the banks; several respondents are fulfilled by the prospect. Employees have gotten education and training and they are dedicated for their job or motivated, and following that they also helped them to execute their job rapidly or proficiently.

HRD practice has an extraordinary impact on the employee's achievement and they are providing education and training and are practicing fair treatment in to all its employees. They are also supplying good training programs and improvement of educational level and after they get further education or training, employees are prepared to recognize more demanding tasks.

After their return from training or education, the HRD departments do not have experience in collecting trainees' feedback; and Human Resource Development programs are not used to improve or provide them efficient training.

Lastly, contribution of the employee's in education or training or achievement of employee's or inspiration connection among them was encouraging or important connection subsists among the variables.

\section{RECOMMENDATIONS}

Enchanting the above study conclusion or results, the researcher recommends the following suggestions to the Lebanese Alpha Banks:

For its employees, banks must maintain raising educational level or also giving trainings to them to use their achievement or the performance may too raise their motivation. To maintain those employees, banks should make short term- plans that are promoting as of its additional education or availing promotional trainings by prospecting to them so that employees may continue extended or provide their involvements.

In the bank, employees finish their education and training thus the Human Resources Development department should collect feedbacks which in turn helps to improve the prospect training plans or educational fields that assist the development of the employees

In long run, for the sustainability of accomplishment, HR must put in position a compatible pay or recompense system that ought to notice the income of educated employees. Both mangers of functional departments or Human Resource Development department must have temporary plan to give the compulsory training for employees, while the achievement assessment statement of the employees explain defectively executed.

When human resource development climate in the bank was established, that was an encouraging effect on achievement or employee's motivation so as to develop their achievement or to enlarge their motivation; banks ought to amplify level of speculation in rising their human resource benefits.

The implementation of efficient Human Resource Development climate by assigning sufficient budgets for the achievement of the climate; this may assist them to develop achievement of their very important source.

Where the outcomes demonstrated that the training isn't at the high level of efficiency and accordingly coordination must be secured among job analysis or allocate suitable people as per the nature of the work needed. It is proposed making job analysis system-related electronically with Human Resource departments, to create suitable decisions in the division or appointment. 
Work to locate the suitable system in the HR planning, including danger zones, or to obtain information about the administrative focuses that are predictable to be vacant in the future, and the work of polls about the issues, pressures, and working conditions that may cause a low level of job satisfaction.

Work on the enhancement of training programs areas, to cover different departments or segments, or the necessary assignments to execute the work, or the require to expand training programs or recognize new training projects that fit the training requires of workers, with the requirement to give specialists identify employees training needs, and to decide suitable courses to cover those requirements. Studies should be connected to the planned practices of a HRM to disseminate the consequences of the present study.

\section{REFERENCES}

Abigail. (2009). How do transformational leaders foster positive employee outcomes? A self-determination-based analysis of employees' needs as mediating links. Journal of Organizational Behavior, 33(8), 1031-1052.

Ajisafe, R., Orifa, R., \& Balogun, J. (2015). Influence of human capital management on organisational performance. Journal of Resource, 7, 25-31.

Bakker, A., \& Leiter, K. (2011). A circumplex model of affect. Journal of Personality and Social Psychology, 39, 1161-1178.

Bande, C. (2015). Research on work engagement is well and alive. European Journal of Work and Organizational Psychology, 20(1), 29-38. Available at: https://doi.org/10.1080/1359432x.2010.510639.

Barber, J. (2004). Skill upgrading within informal training: Lessons from the Indian auto mechanic. International Journal of Training and Development, 8(2), 128-139. Available at: https://doi.org/10.1111/j.1468-2419.2004.00202.x.

Dawodu. (1998). Reward systems and organisation culture: an analysis drawing on three perspectives of culture (Unpublished Doctoral Thesis). University of Greenwich, London, United Kingdom. Zairi, M. (2000). Managing Customer Dissatisfaction through Effective Complaint Management Systems. The TQM Magazine, 12 (5), 331-335.

Dawodu. (2011). Human resource management and business performance. In P.B.Warr (Ed.), Psychology at work. Harmonsworth: Penguin.

González, R. (2003). Core affect and the psychological construction of emotion. Psychological Review, $110(1)$, 145-172.

Hill, \& Lent. (2006). Critical social science, pragmatism and the realities of HRM. The International Journal of Human Resource Management, 21(6), 915-931.

Johnson, K. (2005). Being engaged at work and detached at home: A week-level study on work engagement, psychological detachment, and affect. Work and Stress, 22, 257-276. Available at: https://doi.org/10.1080/02678370802379440.

Kraiger. (2002). Challenges for human resource experts in Global scenerio. International Journal of advancement in Research and Technology, 2(4), 209-214.

Kurtessis. (2015). Influence of work motivation, leadership effectiveness and time management on employees' performance in some selected industries in Ibadan, Oyo State, Nigeria. European Journal of Economics, Finance and Administrative Sciences, 16(1), 7-16.

Lombard, A. (2010). Generational differences in distress, attitudes and incivility among nurses. Journal of Nursing Management, $18(8), 970-980$.

Mathumbu, \& Dodd. (2013). Impact of human resource management practices on employees performance. Middle-East Journal of Scientific Research, 23(2), 329-338.

Medhurst, A. (2011). Psychological capital: Developing the human competitive edge. Oxford, UK: Oxford University Press.

Mitchel. (2007). When birds of a feather flock together and when they do not: Status composition, social dominance orientation, and organizational attractiveness. Journal of Applied Psychology, 92(2), 396-409.

Obisi, \& Anyim. (2012). People management. Amman, Jordan: Dar Al-Safa for Publication and Distribution. 
Patton, I. (1990). When do job demands particularly predict burnout? The moderating role of job resources. Journal of Managerial Psychology, 22, 766-786. Available at: https://doi.org/10.1108/02683940710837714

Rothmann, S., \& Rothmann, J. S. (2010). Factors associated with employee engagement in South Africa. SA Journal of Industrial Psychology, 36(2), 1-12. Available at: https://doi.org/10.4102/sajip.v36i2.925.

Satterfield, \& Hughes. (2007). Recruitment and retention of knowledge workers in taiwan's high technology industry (Unpublished Doctoral Thesis). Cardiff University, Wales, United Kingdom.

Simons, B. (2013). Staying well and engaged when demands are high: The role of psychological detachment. Journal of Applied Psychology, 95(5), 965-976. Available at: https://doi.org/10.1037/a0020032

Singh, A. (2011). Work, happiness, and unhappiness. Mahwah, NJ: Lawrence Erlbaum Associates, Inc.

Yadav, V. (2015). The origin of everyday moods: Managing energy, tension and stress. New York: Oxford University Press.

Online Science Publishing is not responsible or answerable for any loss, damage or liability, etc. caused in relation to/arising out of the use of the content. Any queries should be directed to the corresponding author of the article. 